\title{
Jurist-Diction
}

Volume 3 No. 6, November 2020

\section{Perjanjian Pemagangan yang Tidak Mengatur Ketentuan Besaran Uang Saku Bagi Pemagang}

\author{
Alvian Ferry Mahandi \\ Al.ferrymahandi@gmail.com \\ Universitas Airlangga
}

How to cite:
Alvian Ferry Mahandi,
'Perjanjian Pemagangan yang
Tidak Mengatur Ketentuan
Besaran Uang Saku Bagi
Pemagang' (2020) Vol. 3 No. 6
Jurist-Diction.
Histori artikel:
Submit 1 September 2020;
Diterima 22 September 2020;
Diterbitkan 1 November 2020.
DOI:
10.20473/jd.v3i6.22953

\begin{abstract}
Abstrak
Pada penulisan skripsi ini membahas tentang suatu perjanjian kerja dalam pemagangan yang tidak mengatur adanya besaran uang saku terhadap perjanjian pemagangan yang mlibatkan kedua belah pihak yaitu pemagang dan pengusaha. Dalam hal ini terdapat salah satu hak sebagaimana diatur dalam Undang-Undang Nomor 13 Tahun 2003 tentang Ketenagakerjaan dan Peraturan Menteri Nomor 6 Tahun 2020 tentang penyelenggaraan dalam Negeri. Rumusan masalah yang terdapat dalam skripsi ini adalah Keabsahan perjanjian pemagangan tanpa menyertakan suatu besaran uang saku dan Upaya hukum pemagang terhadap perjanjian pemagangan tanpa menyertakan besaran uang saku. Selanjutnya dalam pemagangan ini terjadi perselisihan industrial maka dapat di selesaikan melalui penyelesaian litigasi atau non-litigasi yang dapat ditarik lebih lanjut dengan bipartite,mediasi,arbitrasi,serta Pengadilan Industrial.

Kata Kunci: Program Pemagangan; Keabsahan Perjanjian; Upaya Hukum.
\end{abstract}

\section{Pendahuluan}

Indonesia merupakan suatu Negara hukum yang didalamnya memiliki suatu aturan hukum yang sangat berguna untuk masyarakat, dan hukum harus memberikan manfaat dan tujuan untuk masyarakat. Dalam melaksanakan aturan hukum jangan sampai terjadi suatu kejadian yang dapat menimbulkan keresahan yang ada pada masyarakat.. hukum juga bertujuan sebagai pelindung dalam hak dan kewajiban di setiap perorangan ataupun berkelompok. ${ }^{1}$ Perlindugan hukum merupakan suatu hal terpenting pada unsur Negara hukum seperti Negara Indonesia. Mengapa dianggap penting? Karena dalam aturan hukum yang telah dibentuk pada suatu Negara telah mengatur pada tiap tiap warga negaranya, namun dapat dirasa perlindungan hukum sangatlah penting dan juga merupakan suatu kewajiban bagi Negara itu

1 Peter Mahmud Marzuki, Pengantar Ilmu Hukum ( Kencana 2008).[155]. 
sendiri. Menurut Philipus M. Hadjon berpendapat bahwa Perlindungan Hukum adalah perlindungan akan harkat dan martabat serta pengakuan terhadap hak-hak asasi manusia yang dimiliki oleh subyek hukum berdasarkan ketentuan hukum dari kesewenangan. Hal ini juga terdapat dalam sila ke lima dalam Pancasila berbunyi “ Keadilan sosial bagi seluruh rakyat Indonesia” serta terdapat juga Undang-Undang Negara Republik Indonesia 1945 pasal 28D ayat (2) "Setiap orang berhak untuk bekerja serta mendapatkan imbalan dan perlakuan yang adil dan layak dalam hubungan kerja".

Khususnya pada hal Ketenagakerjaan, secara umm ketenagakerjaan dibagi menjadi 2(dua), yaitu hukum imperatif dan hukum fakultatif, dimana hukum imperatif hukum yang ditaati secara mutlak, sedangkan hukum fakultatif hukum yang dapat dikesampingkan bahwa hukum fakultatif biasanya menurut pada perjanjian. $^{2}$ Selanjutnya pada Undang-Undang Nomer 13 tahun 2003 Pasal 1 angka 1 menyatakan bahwa, Ketenagakerjaanadalah segala hal yang berhubungan dengan tenaga kerja pada waktu sebelum, selama dan sesudah masa kerja. Dalam hal ketenagakerjaan ini dan sesuai dengan Pasal 1 angka 9 Undang-Undang Nomer 13 Tahun 2013 tentang ketenagakerjaan yang mana membahas tentang maksud dari pelatihan kerja adalah keseluruhan kegiata untuk memberi, memperoleh, meningkatkan, serta mengembangkan kompetensi kerja, produktivitas, disiplin, sikap, dan etos kerja pada tingkat keterampilan dan keahlihan tertentu sesuai dengan jenjang dan kualifikasi jabatan atau pekerjaan. Maksud dari pelatihan kerja ini penulis tujukan kepada orang yang melakukan suatu kegiatan dalam program pemagangan. Pengertian dari pemagangan menurut Undang-Undang Nomor 13 Tahun 2003 adalah bagian dari sistem pelatihan kerja yang diselenggarakan secara terpadu antara pelatihan di lembaga pelatihan dengan bekerja secara langsung di bawah bimbingan dan pengawasan instruktur atau pekerja/buruh yang lebih berpengalaman, dalam proses produksi barang dan/atau jasa di perusahaan, dalam rangka menguasai keterampilan atau keahlian tertentu.

2 Abdul Rachmad Budiono, Hukum Perburuhan di Indonesia (Raja Grafindo Persada 1995).[9]. 
Pada suatu perusahaan tentu melibatkan para pihak yakni pekerja dalam maksud pemagang dan penerima pekerja magang, dalam hal ini tentu keduanya memliki hak dan kewajiban dalam melakukan suatu pekerjaan. Maka dalam hal ini tentu diciptakannya hubungan kerja, dimana hubungan kerja adalah hubungan antara pekerja dan majikan terjadi setelah diadakan perjanjian oleh pekerja dan penerima pekerja, di mana pekerja menyatakan kesanggupannya untuk bekerja pada perusahaan. ${ }^{3}$ Sebagaimana yang tertulis pada Undang-Undang Ketenagakerjaan juga memberikan suatu perwujudan hubungan kerja dalam bentuk penjanjian kerja. perjanjian kerja disini baik dilakukan secara tertulis atau lisan yang mana perjanjian kerja ini atas dasar hak dan kewajiban pemagang dan perusahaan serta ketentuan ketentuan juga dapat pula ditetapkan dalam suatu perjanjian. ${ }^{4}$ Yang mana hak dan kewajiban pemagang antara lain menaati perjanjian pemagangan, serta mengikuti tata tertib pada perusahaan dan kewajiban pada perusahaan antara lain meemenui hak karyawan magang sesuai perjanjian, membimbing karyawan magang sesuai dengan program , memberikan tata tertib pemagangan

Pekerja magang juga tidak memiliki pilihan lain selain melakukan pelatihan kerja terhadap perusahaan yang ia pilih untuk melakukan suatu pekerjaan. Karena secara yuridis dalam hukum perburuhan Dalam hal ini tentu saja pekerja magang akan tidak bebas dalam melakukan pekerjaannya. Maka dalam hal ini perlu adanya campur tangan pada pemerintahan guna mendapatkan perlindungan hukum dalam hubungan kerja pada pemagang

Namun dewasa ini banyak perusahaan yang kurang menaati suatu aturan pemagangan dalam membuat perjanjian pemagangan seperti hak dan kewajiban pemagang dimana perjanjian ini harus sesuai dengan aturan yang berlaku . Salah satunya dalam hak pemberian besaran uang saku. Banyak perusahaan yang tidak mencantumkan besaran uang saku pada perjanjian pemagangan, sedangkan telah jelas diatur dalam Undang-Undang Nomor 13 tahun 2003 tentang Ketenagakerjaan dan Peraturan Menteri Ketenagakerjaan Republik Indonesia Nomor 36 Tahun

\footnotetext{
3 Iman Soepomo, Pengantar Hukum Perburuhan (Djambatan 1990).[53].

4 Lanny Ramly, Hukum ketenagakerjaan (Airlangga University Press 2008).[24].
} 
2016 tentang Penyelenggaraan Pemagang di dalam Negeri bahwa hak dan kewajibanpemagang untuk memperoleh besaran uang saku dari perusahaan yang dipilih untuk program pelatihan kerja atau magang. Banyak tempat perusahaan yang memberlakukan tenaga kerja magang ini merasa dieksploitasi, meskipun tidak semua perusahaan seperti itu. Tujuan dari pemagang memang untuk meningkatkan atau mengembangkan kompetensi sebelum ia terjun di dunia kerja, akibat hal seperti ini banyak perusahaan yang meremehkan sehingga terjadi pengurangan hak dan kewajiban pemagang yang tertulis dalam perjanjian pemagang, salah satunya ketentuan pemberian besaran uang saku kepada pemagang.

Dalam praktik pemagangan hasilnya memang masih banyak perusahaan yang tidak memberikan besararan uang saku. Pada dunia perusahaan tenaga kerja merupakan salah satu pengeluaran terbesar dalam dunia perusahaa, maka dalam hal ini jika tenaga kerja (pemagang) tidak dibayar dapat menguntungkan pihak perusahaan, sementara itu pemagang juga memiliki kebutuhan lain dalam kegiatan sehari-hari. Maka dari itu hal ini tentu dapat merugikan kedua belah pihak yakni pekerja magang (Pemagangan) dan juga Perusahaan. Pemagang tentu tidak mendapatkan haknya dalam pemberian besaran uang saku yang jelas jelas sudah tertulis dalam regulasi pemerintah, begitupun pihak perusahaan pemberi kerja pemagang tidak mematuhi dalam memberikan perjanjian perusahaan berdasarkan ketentuan yang ada pada pemerintahan. Terlebihnya kepada pekerja program pemagangan, walaupun ia hanya berstatus pemagang sejatinya ia adalah pegawai perusahaan yang wajib menerima hak dan kewajibannya pada perusahaan pemaganga

Hubungan kerja merupakan hubungan kedua belah pihak antara pekerja/buruh dengan pihak pemberi pekerjaan, yang mana pekerja/buruh bersedia menyatakan kesanggupannya dalam hal bekerja dan pemberi kerja menyatakan kesanggupannya dalam mempekerjakan pekerja./buruh dan sebagai timbal balik pemberi pekerja memberikan imbalan atau upah kepada pekerja. Dengan maksud hubugan kerja merupakan hubungan kerja terhadap pekerja/buruh dengan pemberi pekerja. Dalam konsep ini pemagangan juga termasuk dalam kategori hukum perburuhan, hukum 
perburuhan juga berasal dari kata arbeidsrecht. Kata arbeidsrecht itu sendiri banyak batasan pengertiannya. Berikut ini merupakan pendapat yang telah dikemukakan oleh sarjana-sarjana, yakni

1. Molenaar

Arbeidsrecht merupakan bagian hukum yang mengatur suatu hubungan antara pekerja dengan pengusaha, antara pekerja dengan pekerja, dan antara pekerja dengan penguasa. Jadi menurut definisi Molenaar, hukum perburuhan melibatkan tiga pihak,yakni pekerja, majikan dan penguasa ( dalam hal ini pemerintah).

2. M.G. Levenbach

Arbeidsrecht merupakan sesuatu yang meliputi hukum yang berkenaan dengan hubungan kerja. dimana pekerjaan itu dilakukan di bawah pimpinan serta keadaan penghidupan yang langsung bersangkut paut dengan hubungan kerja itu. Unsurunsur:

- Di bawah pimpinan; dan

- Keadaan penghidupan yang langsung berhubungan

3. Iman Soepomo

Hukum perburuhan merupakan himpunan peraturan baik tertulis maupun tidak tertulis (lisan), yang berkenaan dengan kejadian dimana seseorang bekerja pada orang lain dengan menerima upah. Unsur-unsur yang harus dicakup dan dikemukakan oleh Soepomo yakni:

- Himpunan peraturan;

- Bekerja pada orang lain (di bawah pimpinan orang lain);

- Menerima upah;

- Soal-soal yang berkenan.

Oleh sebabnya penulis membahas terkait hubungan kerja antara pemagang dengan perusahaan yang mana dalam pasal 1 ayat (11) Undang-Undang Nomor 13 tahun 2003 tentang Ketenagakerjaan menjelaskan bahwa "Pemagang adalah bagian dari sistem pelatihan kerja yang diselenggarakan secara terpadu antara pelatihan di lembaga pelatihan dengan bekerja secara langsung di bawah bimbingan dan pengawasan instruktur atau pekerja/buruh yang lebih berpengalaman, dalam 
proses peroduksi dan/jasa di perusahaan, dalam rangka menguasai keterampilan atau keahlihan tertentu". Undang-Undang Ketenagakerjaan mengkategorikan bahwa pemagangan merupakan salah satu kegiatan pelatihan kerja sebagaimana diatur pada pasal 21. Pemagangan dibagi menjadi 2 jenis, diantaranya Pemagangan Didalam Negeri dan Pemagangan Diluar Negeri. Keduanya diatur dalam Pasal 24 Undang-Undang Ketenagakerjaan, dan lebih jelasnya di Dalam peraturan menteri Tenaga Kerja dan Transmigrasi (Permenakertrans). Pemagangan diLuar Negeri diatur dalam Pemenakertrans 08/Per/Men/V/2008 Tentang Penyelenggaraan Pemagangan Diluar Negeri. Dalam kegiatan pemagangan tentunya terdapat suatu perjanjian atau kontrak kerja yang mana perjanjian kerja dalam Undang-Undang Nomor 13 Tahun 2003 Tentang Ketenagakerjaan pada Pasal 1 angka 14 yakni "Perjanjian kerja adalah suatu perjanjian antara pekerja/buruh dan pengusaha atau pemberi kerja yang memuat syarat-syarat kerja hak dan kewajiban kedua belah pihak" maka dapat dipahami bahwa dalam suatu hubungan kerja sangatlah lazim jika didalamnya terdapat suatu perjanian kerja, guna membktikan bahwa di dunia pekerjaan tidak berjalan begitu saja. Berdasarkan pengertian perjanjian kerja diatas, dapat ditarik bahwa perjanjian kerja juga memiliki unsur-unsur dalam membuat suatu perjajian kerja yakni:

a. Unsur Pekerjaan

Suatu perjanjian kerja harus terdapat suatu pekerjaan yang dapat diperjanjikan (objek perjanjian). Bahwa seharusnya pekerjaan tersebut harus dilakukan dengan sendiri oleh pekerja, jika ingin menyuruh orang lain untuk membantu suatu perkerjaan harus dengan izin seorang majikan. Hal ini juga dijelaskan pada pasal 1603 KUH Perdata byakni "buruh wajib melakukan pekerjaannya sendiri, hanya dengan seizing majikan ia dapat menyuruh orang ketiga untuk menggantikannya” karena sifat dalam pekerjaan yang dilakukan oleh pekerja itu sangat pribadi karena dilakukan sesuai dengan keterampilannya atau keahlihannya.

b. Unsur Perintah

Pekerjaan yang diberikan kepada pekerjaan oleh pengusaa adalah pekerja yang bersangkutan haruslah taat dengan adanya perintah yang diberi oleh 
pengusaha dengan sesuai apayang diperjanjkan, maka disinilah perbedaan antara hubungan kerja dengan hubungan lainnya.

c. Unsur Pengupahan

Pengupahan merupakan peran yang sangat penting dalam hubungan kerja (perjanjian kerja). dapat dikatakan bahwa tujuan dari seorang pekerja adalah untuk mendapatkan suatu upah dari hasil jerih payah selama ia bekerja pada pengusaha. Maka dalam hubungan kerja jika tidak ada unsur upah, tidak dapat dikatakan sebagai hubungan kerja.

\section{Syarat sahnya perjajian kerja}

Syarat perjanjian merupakan sebagian dari perjanjian pada umumnya., maka dalam membuat suatu perjanjian kerja harus memenuhi syarat sah perjanjian sebagaimana diatur dalam KUH Perdata Pasal 1320. Ketentuan Undang-Undang Nomor 13 Tahun 2003 tentang Ketenagakerjaan menyebutkan bahwa perjanjian kerja dapat dibuat atas dasar sebagai berikut:

a. Adanya kesepakatan kedua belah pihak

Kesepakatan kedua belah pihak yang biasa disebut dengan kesepakatan bagi yang mengikatkan dirinya sebagaimana maksud bahwa pihak yang mengadakan perjanjian kerja harus didasari dengn kata setuju atau tidak setuju dalam hal yang di perjanjikan oleh kedua belah pihak.

b. Kemampuan atau kecakapan dalam melakukan perbuatan hukum

Kedua belah pihak (pekerja dan pengusaha) harus mampu atau cakap dalam membuat suatu perjanjian kerja. ketentuan hukum ketenagakerjaan memberikan batasan umur minimal 18 tahun (pasal 1 angka 26 Undang-Undang Nomor 13 Tahun 2003) yang bertujuan untuk seorang dipandang cakap hukum jika yang bersangkutan dalam perjanjian telah cukup umur.

c. Adanya pekerjaan yang diperjanjikan

Dalam suatu perjanjian kerja tentunya terdapat suatu pekerjaan yang diperjanjikan, hal ini merupakan obyek dari perjanjian kerja antara pekerja dan pengusaha. 
d. Pekerjaan yang diperjanjikan tidak boleh bertentangan dengan ketertiban umum, kesusilaan, dan ketentuan peraturan perundang-undangan yang berlaku.

Dalam keempat syarat tersebut bersifat kumulatif yang mana semuanya harus dipenuhi baru perjanjian tersebut dapat dikatakan sah. Syarat kesepakatan kedua belah pihan dan kecapakan kedua belah pihak dalam membuat perjanjian dalam hukum perdata dapat disebut syarat subjektif karena menyangkut mengenai orang yang membuat suatu perjanjian. Sedangkan syarat adanya pekerjaan yang diperjanjikan dan pekerjaan yang dijanjikan harus halal dapat disebutkan sebagai syarat objektif karena syarat tersebut menyangkut objek suatu perjanjian kedua belah pihak. Jika syarat tersebut (objektif) tidak dipenuhi dalam syarat sah perjanjian kerja, maka perjanjian itu dianggap batal demi hukum atau dianggap tidak pernah ada.

\section{Hubungan hukum dalam pemagangan}

Hubungan hukum merupakan hubungan yang diatur oleh hukum. Hubungan hukum yang diatur oleh hukum itu menyangkut hak dan kewajiban., biasa terjadi antara sesama subjek hukum dan antar subjek hukum dengan barang, hubungan hukum antara sesame subjek hukum dapet terjadi antara seorang dengan seorang lainnya, antara seseorang dan suatu badan hukum, serta antara suatu badan hukum dan badan hukum lainnya. Sedangkan menurut Undang-Undang no 13 Tahun 2003 tetang Ketenagakerjaan, pemagang merupakan bagian dari pelatihan kerja yang dilakukan secara terpadu antara lain lembaga pelatihan kerja dengan praktik kerja secara langsung dibawah pengawasan serta bimbingan oleh pekerja sudah berpengalaman atau senior.

Kegiatan pemagangan dibagi menjadi 2 yakni Pemagangan Dalam Negeri dan Pemgangan Luar Negeri. Keduanya diatur pada pasal 24 Undang-Undang Ketenagakerjaan dan secara spesifik pada PermenakerPemagangan Dalam Negeri diatur dalam Peraturan Menteri Nomor 6 Tahun 2020 tentang Penyelenggaraan Pemagangan Dalam Negeri.

Dalam perusahaan, Pemagangan di laksanakan dengan tujuan untuk mendapatkan seorang tenaga kerja, tentunya tenaga kerja yang memiliki keterampilan 
yang sesuai dengan kualifikasi yang dibutuhkan.Sementara itu pemagangan bagi peserta magang berguna untuk mendapatkan ilmu dalam bekerja serta keterampilan yang diperlukan oleh pemagang.Namun dalam sistem pemagangan pada perusahaan bukan merupakan hubungan kerja antara perusahaan dengan pekerja/ buruh, dikarenakan peserta pemagangan tidak memiliki hubungan kerja dengan perusahaan (bukan pekerja/karyawan perusahaan). Maka hubungan pada peserta magang dengan perusahaan hanya terikat dalam perjanjian pemagangan bukan perjanjian kerja hal ini dalam konteks hubungan kerja.

Oleh sebab itu sebagaimana yang terkandung dalam Pasal 9 Peraturan Menteri Nomor 6 Tahun 2016. Perserta Pemagangan Dalam Negeri meliputi Pencari kerja dan/atau pekerja yang akan ditingkatkan Kompetensinya. Dengan maksud Pencari Kerja belum mempunyai Hubungan kerja dengan perusahaan karena tujuan perncari pekerja dalam sistem pemagangan ini untuk mengikuti Pelatihan Kerja guna mendapatkan pekerjaan, sedangkan Pekerja yang akan ditingkatkan Kompetensinya statusnya sudah sebagai pekerja dalam perusahaan dan mempunyai Hubungan Kerja terhadap perusahaan, tetapi dalam hal ini pekerja tersebut menjadi peserta pemagangan dikarenakan perusahaan bertujuan untuk meningkatkan pekerja kepada lembaga perusahaan lain guna meningkatkan kompetensinya. Selanutnya terdapat juga Pemerintah Provinsi Jawa Timur membuat suatu kebijakan Daerah mengenai Pemagangan Didalam Negeri dalam hal ini menerbitkan peraturan Daerah Jawa Timur Nomor 8 Tahun 2016 tentang Penyelenggaraan Ketenagakerjaan, Perda Jatim ini berisi tentang penempatan tenaga kerja dan kesempatan kerja, pelatihan dan pemagangan kerja, dan lain lain yang masih berhubuungan dengan penyelenggaraan ketenagakerjaan di Provinsi Jawa Timur. Keberadaan Peraturan Daerah ini adalah untuk menjamin hak-hak dasar pada tenaga kerja/buruh serta kesempatan dan perlakuan yang sama dan dilakukan secara terencana, terstruktur, dan terpadu guna meningkatkan kesejahteraan masyarakat di Provinsi Jawa Timur.

Dalam sistem pemagangan juga harus jelas menyangkut adanya hak dan kewajiban antara pemagang dengan perusahaan atau sebaliknya. Kewajiban peserta pemagangan antara lain harus mentaati perjanjian pemagangan, mentaai tata tertib 
perusahaan, mentaati program-program pemagangan dalam perusahaan. Serta kewajiban yang diberikan perusahaan oleh peserta pemagangan antara lain member uang saku atau uang transportasi pada peserta magang, member fasilitas pelatihan; instruktur pelatihan kerja, perlengkapan saat melakukan pekerjaan, kesehatan serta keselamatan kerja, memberikan sertifikat, jangka waktu. Proses pemagangan tidak sah jika pemagangan yang disertakan tidak melalui perjanian kerja, dan status peserta magang dapat berganti sebagai pekerja/buruh.

Dengan lanjut, terkait penyelenggaraan suatu kegiatan pelatihan kerja, kedua belah pihak yakni perusahaan maupun peserta pemagangan juga harus memenuhi beberapa syarat dan persyaratan dalam pemagangan harus mengikuti sebagaimana persyaratan yang terkandung dalam Peraturan Menteri Nomor 6 Tahun 2020 , diantaranya:

- Program-program pemagangan;

- Sarana, dan prasarana terhadap peserta magang;

- Pembimbing pemagangan.

Sedangkan syarat-syarat pada peserta pemagangan:

- Usia minimal 17 tahun;

- Sehat jasmani dan rohani

- Memiliki bakat, minat, serta memenuhi persyaratan yang sesuai dengan program pemagangan;

- Lulus seleksi; dan

- Menandatangani perjanjian pemagangan.

\section{Keabsahan Perjanjian Pemagangan}

Dalam melaksanakan suatu kegiatan pemagangan tidaklah bisa berjalan dengan lancar atau dapat berlaksana begitu saja. Kegiatan Pemagangan harus di dasari dengan perjanjian tertulis antara peserta magaang dengan perusahaan sebagaiman perjanjian ini diatur dalam Undang-Undang Ketenagakerjaan Pasal 22 ayat (1). Oleh sebab itu pemagangan wajib melakukan perjanjian sebelum berlangsungnya kegiatan pemagangan dan perjanjian tersebut harus dilakukan secara tertulis.

Pada Pasal 1313 BW, perjanjian merupakan suatu perbuatan dengan mana satu orang atau lebih mengikatkan diri terhadap satu orang lain atau lebih. Perjanjian 
pemagangan merupakan suatu turunan perjanjian pada umumnya. Perjanjian pemagangan merupaka tergolong dalam perjanjian yang tak bernama (innominaat), maksud dari golongan ini yakni perjanjian yang timbul,tumbuh dan berkembang dalam praktek sebagaimana diatur dalam Pasal 1319 BW. Sehingga keabsahaannya juga mengikuti keabsahan perjanjian pada umumnya sebagaimana syarat sahnya suatu perjanjian juga diatur dalam Pasal 1320 BW yakni:

1. Kesepakatan dalam mengikatkan dirinya;

2. Kecakapan untuk membuat suatu perikatan;

3. Suatu pokok persoalan tertentu;

4. Kuasa yang diperbolehkan.

Maka dalam keempat syarat diatas merupakan syarat yang bersifat kumulatif, yang artinya semuanya harus dipenuhi oleh kedua belah pihak. Apabila keempat syarat ini ada yang tidak dipenuhi maka mempunyai akibat hukum tersendiri. Terdapat pada syarat kesatu dan kedua merupakan syarat yang subyektif, yakni apabila tidak terpenuhi atau dilanggar oleh pihak yang bersangkutan maka berakibatkan perjanjian dapat dibatalkan. Sedangan pada syarat ketiga dan keempat merupakan syarat yang obyektif, yakni apabila perjanjian tidak terpenuhi atau dilanggar oleh pihak maka berakibatkan perjanjian ini batal demi hukum.

Pada unsur kecakapan, dalam perusahaan atau dalam pemagang sudah seharusnya orang tersebut memiliki kecakapan dan berwenang yang mana pemagang dianggap cakap apabila telam mencapai usia kedewasaan yakni berusia sekurangnya 18 tahun, yang mana sudah di tentukan dalam Undang-Undang Ketenagakerjaan Pasal 1 angka 26 Undang-Undang Ketenagakerjaan. Sedangkan unsur kecakapan dalam perusahaan sama seperti pemagang, jika ia merupakan perseorangan. Namun jika perusahan berbentuk Badan Hukum, maka Badan hukum yang bersangkutan harus terdaftar pada Kementrian Hukum dan HAM, serta orang yang terlibat dalam perjanjian pemagangan sudah sehausnya orang tersebut memiliki kewenangan dalam perusahaannya.

Pemagangan juga menjadi peranan penting karena di dalam pemagangan terdapat beberapa tujuan yakni mempromosikan formasi pembelajaran dan keterampilan, serta memfasilitasi tenaga kerja (pemagang) dengan memberi 
bantuan dalam dunia pendidikan dan dunia kerja. pemagangan dapat membantu perusahaan dalam pemenuhan kebutuhan tenaga kerja dan menyediakan pelatihan keterampilan bagi kaum muda untuk mempersiapkan mereka dalam menghadapi dunia pekerjaan.

Manfaat yang bisa didapatkan dalam pelaksanaan pemagangan juga tidak hanya dirasakan pihak perusahaan yang dapat menghasilkan tenaga kerja sesuai dengan standar industri dan kebutuhan perusahaan, namun peserta pemagangan itu sendiri mendapatkan kesempatan untuk menerima pelatihan, bukan hanya untuk mengasah keterampilan yang sesuai dengan standar industri/perusahaan, namun juga untuk mendapatkan secara langsung pelatihan secara teknikalserta keterampilan kerja inti yang dapat meningkatkan kinerjanya. Selain itu peserta magang juga dapat menguasai keterampilan teknis danketerampilan non-teknis atau soft-skillpeserta magang. Dan menumbuhkan suasana kerja yang mendorong terciptanya inovasi dari peserta magang atau pekerja di perusahaan yang bersangkutan

Selanjutnya, ketentuan-ketentuan yang tertuang dalam suatu perjanjian harus sebagaimana diatur dalam Pasal 22 ayat (2) Undang-Undang Ketenagakerjaan. Yang mana menyangkut seluruh hak dan kewajiban para pihak dalam program pemagangan.

1. Hak dan Kewajiban penyelenggara pemagangan (perusahaan)

1) Memanfaatkan hasil kerja karyawan magang guna meningkatkan produktivitas perusahaan

Perusahaan berhak mendapatkan pemikiran-pemikiran cerdas dari mereka. Tentu saja dalam hal ini pemagang juga butuh arahan serta ilmu sebanyak mungkn dari perusahaan.

2) Memberlakukan tata tertib dan perjanjian pemagangan yang telah disepakati para pihak

Perusahaan berhak menerapkan tata tertib perusahaan kepada pemagang sama hanya seperti pekerja lainnya, tetapi hanya 1 saja yang membedakan pekerja dengan pemagang yakni jangka waktu serta uang saku 
1. Kewajiban penyelenggar pemagangan (perusahaan)

a. Membimbing karyawan magang sesuai dengan program pemagangan Perusahaan memiliki kewajiban dalam membuat rancangan program pemagangan. Pada pelaksanaan nya, praktik dan teori harus memiliki proporsi yang sesuai. Dimana prakteknya $75 \%$ dari total waktu pemagangan berlangsung, serta teori $25 \%$ dari total waktu program pemagangan. Waktu tersebut tentu saja di tentukan berdasarkan jam kerja yang berlaku pada perusahaan.

b. Memberikan alat perlindungan sesuai dengan persyaratan (K3)

K3 merupakan Keamanan, Keselamatan, dan Kesehatan kerja guna meningkatkan dan memelihara kesehatan mental, fisik,dan social bagi semua karyawannya.

c. Memberikan perlindungan asuransi

Perusahaan wajib memberikan asuransi kecelakaan kerja dan kematian kepada peserta pemagangan melalui program BPJS Ketenagakerjaan dan Kesehatan. Bahwa perusahaan dapat dikatakan sudah memberikan finansial kepada karyawan magang

d. Menenuhi hak peserta pemagangan sesuai dengan perjanjian

Dalam membuat perjanjian pemagangan, perusahaan wajib memuat bahwa perusahaan dapat memenuhi hak-hak peserta magang .hak tersebut adalah pelatihan kerja, alat kerja, evaluasi, besaran uang saku, sertifikat.

2. Kewajiban Peserta Pemagangan

Kewajiban dan hak pekerja pemagangan sebagaimana terkadung dalam PERATURAN MENTERI NOMOR 6 TAHUN 2020 tentang Penyelenggaraan Pemagangan didalam Negeri sebagai berikut.

a. Hak peserta pemagangan

Peserta Pemagangan mempunyai hak untuk:

- memperoleh bimbingan dari Pembimbing Pemagangan atau instruktur;

- memperoleh pemenuhan hak sesuai dengan Perjanjian Pemagangan;

- memperoleh fasilitas keselamatan dan kesehatan kerja selama mengikuti Pemagangan; 
- memperoleh uang saku;

- diikutsertakan dalam program jaminan sosial;dan

- memperoleh sertifikat Pemagangan atau suratketerangan telah mengikuti Pemagangan.

Selanjutnya materi yang dimuat oleh penulis adalah perjanjian pemagangan menyangkut tentang perjanjian pemagangan mengenai hak dan kewajiban peserta magang dalam menerimah hasil jerih payah ketika bekerja yaitu berupa besaran uang saku. Hak peserta pemagangan antara lain memperoleh uang saku dan/atau uang transpor, memperoleh jaminan sosial tenaga kerja, memperoleh sertifikat apabila lulus di akhir program. Tapi masih banyak perusahaan yang memberlakukan magang secara cuma-cuma. Namun, banyak juga perusahaan yang sekarang sudah sadar dan memberlakukan uang saku bagi karyawan magang. Dalam peraturan menteri ketenagakerjaan memang tidak dijabarkan secara jelas mengenai besaran yang wajib dikeluarkan oleh perusahaan mengenai uang saku. Maka perusahaan yang memperkerjakan pemagang dapat mengakumulasi pengeluaran besaran yang mesti dikeluarkan untuk uang saku berdasarkan jam dan beban kerja.

Secaraa yuridis materi muatan perjanjian pemagangan ini sudah di tentukan dalam Undang-Undang Ketenagakerjaan. Ketentuan-ketentuan tersebut sudah seharusnya di terapkan oleh para pihak pada saat melakukan perjanjian. Sehingga, pihak yang terlibat dibolehkan dalam menambahkan klausula atau ketentuan lain sepanjang tidak merugikan kedua belah pihak dan yang paling penting ketentuan ketentuan yang diperjanjikan sesuai dengan ketentuan pada umumnya yakni tidak melanggar Undang-Undang yang ada. Pada dasarnya program pemagangan sudah seharusnya diberi uang saku, dan uamg transport bagi peserta pemagangan karena dalam pemberiang uang saku ini merupakan syarat yang harus dicantumkan dalam membuat suatu perjanjian. Jika perjanjian ingin dianggap sah perusahaan dalam membuat perjanjian harus mencantumkan syarat syarat yang sesuai pada peraturan yang di tetapkan oleh Negara. Dan setiap perjanjian yang telah dibuat oleh kedua belah pihak akan dianggap sah dan mengikah sejak adanya kesepakatan seperti yang diatur dalam pasal 1320 BW. Oleh sebab itu perjanjian pemagangan termasuk dalam perjanjian formil karena perjanjian pemagangan ini harus dibuat 
dalam tertulis serta ditandatangani sebagaimana yang di syaratkan dalam Peraturan Menteri saat ini yakni Peraturan Mentri Nomor 6 Tahun 2020. Jika perjanjian itu melanggar Undang-Undang maka dapat dikatakan perjanjian ini Batal Demi Hukum dan posisi Peserta Pemagang dapat berganti menjadi Pekerja/Buruh.

\section{Upaya Hukum Penyelesaian Perselisihan Hubungan Industrial}

Dalam peristiwa pemagangan terjadi suatu perselisihan perburuhan, hal ini disebabkan karena adanya perbedaan antara peserta pemagangan dengan pelaksana pemagangan (perusahaan). Berbicara tentang kedudukan, memang kedudukan peserta magang memiliki kedudukan dibawah perusahaaan, sehingga terlalu banyak kasus peserta pemagangan merasa dirugikan oleh penyelenggara pemagangan (perusahaan). Sengketa perburuhan yang terjadi didalam negeri seringkali muncul karna beberapa faktor,yakni :

- Masalah terkait pemberian upah dibawah minimum;

- Pemutusan hubungan kerja; dan

- Terjadinya wanprestasi yang disebabkan oleh salah satu pihak.

Pada aspek hukum perburuhan, terdapat berbagai upaya hukum disaat terjadinya suatu perselisihan antar pihak yakni: upaya hukum melalui litigasi atau pun non-litigasi yang kemudian dilanjut dengan upaya hukum mediasi serta terdapat juga lembaga-lembaga perundingan bipartit dan tripartit, konsiliasi, arbitrase dan melalui pengadilan. Berikut merupakan lembaga peradilan yang dijalankan oleh institusi Negara, sedangkan penyelesaian pada luar pengadilan dilakukan sesuai dengan pilihan serta kesepakatan kedua belah pihak sebagaimana wujud aktualisasi dalam menyelesesaikan penyelesaian sengketa ini. Dengan hal inilah yang akhirnya dapat dijadikan pedoman dalam membuat Undang-Undang terkait perselisihan dalam penyelesaian sengketa.

Undang-Undang Nomor 2 Tahun 2004 tentang Penyelesaian Perselisihan Hubungan Industrial ( PPHI ) membagi perselisihan hubungan industrial ke beberapa jenis, yaitu:

1. Perselisihan Hak merupakan perselisihan yang terjadi akibat tidak dipenuhinya 
suatu hak pada salah satu pihak akibat adanya perbedaan dalam suatu penafsiran terhadap ketentuan peraturan perundang-undangan, perjanjian kerja, peraturan perusahaan, atau pejanjian kerjasaama. ( Pasal 1 angka 2 Undang-Undang Nomor 2 Tahun 2004).

2. Perselisihan Kepentingan merupakan perselisihan yang timbul sebab tidak adanya kesesuaian pendapat mengenai pembuatan,dan/atau perubahan syarat kerja yang ditetapkan dalam perjanjian, peraturan perusahaan, atau perjanjian kerja sama. ( Pasal 1 angka 3 Undang-Undang Nomor 2 Tahun 2004).

3. Perselisihan antar serikat pekerja/serikat buruh yang terdapat dalam Pasal 1 angka 5 Undang-Undang Nomor 2 Tahun 2004 merupakan perselisihan antara serikat pekerja/buruh merupakan perselisihan yang terjadi karena ketidak adanya persesuaian paham mengenai keanggotaan, pelaksanaan hak, kewajiban perserikatan pekerjaan.

\section{Kesimpulan}

Bahwa Perjanjiann pemagangan dapat terjadi antara perusahaan (tempat pemagangan) dengan pencari kerja/ pekerja yang ingin meningkatkan kompetensinya. dan didalam perjanjian tersebut terdapat beberapa hal yang harus dimuat didalamnya sebagaimana pada pasal 10 ayat 2 Permenaker Nomor 6 Tahun 2020 salah satunya yakni memberikan besaran uang saku. Jika dalam perjanjian pemagangan tidak memberikan uang saku maka perjanjian tersebut dapat dikatakan melanggar permenaker sehingga dapat batal demi hukum.

\section{Daftar Bacaan}

\section{Buku}

Peter Mahmud Marzuki, Pengantar Ilmu Hukum (Kencana 2008).

Abdul Rachmad Budiono, Hukum Perburuhan Indonesia (Raja Grafindo Persada 1995).

Peter Mahmud Marzuki, Penelitian Hukum (Kencana Prenada Media Group 2011). 
Iman Soepomo, Pengantar Hukum Perburuhan (Djambatan 1990).

Lanny Ramly, Hukum ketenagakerjaan (Airlangga University Press 2008).

\section{Perundang-Undangan}

Burgerlijk Wetboek (BW) atau Kitab Undang-Undang Hukum Perdata (KUHPer).

Peraturan Menteri Nomor 6 Tahun 2020 tentang Penyelenggaraan Pemagangan didalam Negeri.

Peraturan Menteri Nomor 33 Tahun 2016 tentang Penyelenggaraan Pemagangan Dalam Negeri.

Peraturan Daerah Jawa Timur Nomor 8 Tahun 2016 tentang Penyelenggaraan Ketenagakerjaan.

Undang-Undang Dasar Negara Republik Indonesia Tahun 1945.

Undang-Undang Nomor 13 Tahun 2003 tentang Ketenagakerjaan.

Undang-Undang Nomor 2 Tahun 2004 tentang Penyelesaian Perselisiham Hubungan Industrial. 
1996

Alvian Ferry: Perjanjian Pemagangan yang

--halaman ini sengaja dibiarkan kosong-- 